\title{
Teilhard's Catholicity: An Evolution of Consciousness
}

\author{
Andrew Del Rossi
}

Independent Researcher, Paoli, PA 19301, USA; adr@daylesford.org

\begin{abstract}
Pierre Teilhard de Chardin, Jesuit mystic and scientist, was a groundbreaking thinker whose synthesis of evolution and faith challenges the faithful to see God in a more expansive perspective. Teilhard's vision ultimately posits that the universe is evolving closer in relationship with the Divine. Through the increase in material complexity and consciousness, the spiritual power of the cosmos is revealed, identified by Teilhard as becoming personalized in the Cosmic Christ. This article uses the four marks of the Catholic Church—one, holy, universal, and apostolic — to highlight the catholicity, or universality, of Teilhard's life and vision and its relevance for seekers who probe for God's presence in all things.
\end{abstract}

Keywords: Teilhard de Chardin; Cosmic Christ; Omega Point; spirituality; catholic; consciousness; cosmology; evolution; complexity; mysticism

\section{Introduction}

Pierre Teilhard de Chardin, a French Jesuit mystic and scientist, produced a profound synthesis of evolution and faith and is one of the most revolutionary thinkers of the twentieth century. He was a noted paleontologist, and his ideas were influential within the Catholic Church, particularly upon the Second Vatican Council. Working with complex subjects in the formation of the universe and the destiny of the human person, Teilhard's ideas provide an expansive perspective on faith by going beyond dogmatic limitation. This article will explore the catholicity of Teilhard's life and work by following the four marks of the church as defined in the Nicene Creed: "I believe in one, holy, catholic, and apostolic church".

The proper noun "Catholic" is typically used in reference to the Roman Catholic Church as an institutionalized and organized faith. The word catholic means "universal", and the use of the word applies to different Christian denominations that describe themselves in accordance with the four marks of the church. Teilhard's personal journey unfolded in a way where he was able to build on his experiences and integrate them into his vision of a universe created from and completed in the image of God's oneness and wholeness. He came to experience this vision through learning to see the material world as a holy place, vibrating with divine intelligence, structure, and direction. Teilhard's radical vision empowered him to become aware of the personal character of the cosmos in the Universal Christ, in whom all things hold together by the grace of the movement and molding of the Spirit, who drives apostolic engagement and conscious evolution.

Empowered by his faith, Teilhard experienced and understood evolution as the increase in awareness of the Divine within the world. Teilhard's faith is rooted in his belief that evolution is moving to a point of wholeness in God. Thus, the human person is seen as an organism capable of growing into a fuller awareness of itself in communion with the universe. According to Teilhard:

Faith, as we understand it ... is certainly not only intellectual adherence to dogma. In a much deeper sense, it is belief in God filled with confidence in his beneficial strength that knowledge of this divine being can arouse in us (Teilhard de Chardin 1960, p. 126).

Faith can be considered an essential precursor for human fulfillment; it is an inclination to seek more in life, to stretch beyond oneself. Thus, Teilhard's catholicity is to be 
distinguished from his Catholicism, which as an -ism refers to a specific doctrine, system, or theory. Instead, his catholicity is the embodiment of his spirituality, which was steeped in the Roman Catholic tradition, yet demonstrates an integrated awareness that expands beyond the boundaries of the dogmatic faith and communicates a truly universal message.

2. One

An Evolving Consciousness of Oneness

Teilhard's scientific reflections were amplified by his visionary experiences and provide insight into the evolution of universe, the place of the human person, and how wholeness is achieved through integral relationship. Above all, Teilhard's vision is one of wholeness and oneness. Teilhard non-dualistically synthesizes his love of God and faith in the world to allow for the emergence of a consciousness that is not "either/or", rather "both/and", or an awareness capable of holdings all things together.

Pierre Teilhard de Chardin was born on 1 May 1881 in his family's château of Sarcenat, near the provincial capital, Clermont-Ferrand, France. His father was an amateur naturalist and his mother was a devout Catholic. Embracing both his love of the world and love of God, he was ordained a priest in the Society of Jesus and also earned his doctorate in paleontology. He began a promising academic career teaching chemistry and physics at the Jesuit College of the Holy Family in Cairo, Egypt. After studying theology in the United Kingdom, Teilhard conducted research in the laboratory and worked in the field for the National Museum of Natural History in Paris. In 1914, at the age of thirty-three, Teilhard was mobilized in the 8th Moroccan Rifle division of the French Army as a stretcher-bearer during World War I. After the war, he traveled to China to continue research in the field. He spent the remainder of his life traveling the world giving lectures, attending conferences, and working as a researcher for the Wenner Gren Foundation of Anthropological Research. He died at the age of 73 in New York City on 10 April 1955, Easter Sunday.

As a boy growing up in south central France, Teilhard sought what he calls le Tout (the All), or the ultimate element of permanence at the core of creation. His fixation began with collecting metals he found on his family's land and then shifted to rocks. He pursued his proclivity through his doctoral studies and teaching, yet it was not until reading Henri Bergson's 1907 Creative Evolution that Teilhard began to define the All that he was searching for, the Ultimate Element at the core of all things. Bergson proposes that evolution is the result of a creative impulse that the human person has a capacity to embody. Evolution, according to Teilhard, is the ongoing and unfolding process of the creative impulse, which is personalized in the human person and thus it reaches its apex in personal relationship with the transcendent.

The creative impulse on Earth began with the elemental formation of its core, followed by its geological development and then the emergence of the biosphere. The interconnectivity and interdependence of life bursting forth in the biosphere demonstrates communication and relationship beyond bio-chemical information transfer and reveals another level of evolution's progress: a noetic or thinking layer called the noosphere. Though the human ability to communicate and travel globally are exemplary of the noosphere, this thinking, social layer of evolution can be found throughout nature, as in colonies of ants, hives of bees, and mycelial networks. The human person, therefore, has a distinct objective. Beyond the goal of survival, there is a more critical outcome toward which the human person is to posit itself: the ascent of consciousness. For the human person, recognized Teilhard, holds the capacity for conscious relationship with not only itself and other people, but also with the Divine. This requires the human person to have the faith to "test every barrier, try every path, plumb every abyss" to discern the way forward (Teilhard de Chardin 1960, p. 70). The pinnacle of human evolution, according to Teilhard, is to be in relationship with the All and living as a conscious expression of wholeness and divine love.

Teilhard's thought was truly revolutionary in its time, and his work was viewed by some with skepticism and suspicion. Despite the challenges and complexities that he faced as a result of his radical vision, he remained optimistic and faithful. His disposition holds 
true to his observation that "a richer and better organized structure will correspond to the more developed consciousness (Teilhard de Chardin 1959, p. 60)". Greater material complexity means greater consciousness. Increased consciousness results in an expanded awareness of the spiritual nature of matter, an expanded awareness of the whole. Humanity's spiritual development is bound to its growth in consciousness. Humanity has the capability for self-awareness so that it might continue evolution's ascent to higher levels of consciousness. Therefore, in drawing the world closer to God, the ascent of evolution can also be understood as the call to holiness.

\section{Holy}

\subsection{Divinization}

The response to the call to holiness is integration and wholeness. In becoming more conscious, the human person faces the impetus to integrate all aspects of its being, for the human person is consciousness becoming aware of itself. Teilhard understands that human consciousness stands out by much more than the material complexity of the human brain-it is identifiable through its inclination toward conscious, or spiritual, relationship.

Teilhard's theology is heavily influenced by the work of the Greek Church Fathers. The Eastern Fathers acknowledged that through the human person relationship can be understood, for relationship exists in the human on a conscious level. The early Fathers turned to Sacred Scripture for direction and found that the human person is to be in relationship with the Divine: "And God said, 'Let us make man according to our image and likeness' (Gen. 1:26)".

Ultimately, the Greek Fathers' speculations on image and likeness led them to a common perspective on divinization, or the "deification" of the human person. The Greek Fathers saw wholeness as achieved when the human person is in fullness of relationship with God. The Eastern Fathers-from Irenaeus, to Clement of Alexandria, to Justin Martyr, to Athanasius of Alexandria, to Gregory of Nyssa, to Gregory of Nazaianzus-acclaim this in some fashion: "For God was made man that man might be made God" (Athanasius 2011, p. 54). This is in accord with the teaching of the Catechism of the Catholic Church:

The Word became flesh to make us "partakers of the divine nature": For this is why the Word became man, and the Son of God became the Son of man: so that man, by entering into communion with the Word and thus receiving divine sonship, might become a son of God". "For the Son of God became man so that we might become God. The only-begotten Son of God, wanting to make us sharers in his divinity, assumed our nature, so that he, made man, might make men gods" (Catholic Church 1993, Article 460).

St. John of the Cross, the Carmelite mystic, describes this state of being as "conscious realization of one's substantial union" (St. John of the Cross 2008, p. 453) with God. ${ }^{1}$ Since creation comes from God, exists in God, and ultimately returns to God, the "deification" of the human person is not where humans become God, but instead "what happens is that we consciously realize the divinity that has always been ours" (Marion 2011, p. 166). This happens when human consciousness evolves to the awareness of one's ontological connection to the Divine through the universal call to holiness and wholeness.

Teilhard held a special appreciation for the Eastern Fathers because he found their thought to be more reflective of his understanding of a universe in movement. He writes, "one finds an astonishing anticipation of our modern views on progress in the Greek Fathers" (Teilhard de Chardin 1969c, p. 167). Unlike the Latin Fathers, who generally agreed upon a "fixed universe", their Greek counterparts recognized a more dynamic cosmogony. The theology of the Greek Fathers resonated with Teilhard, for he could not dismiss the undeniable evidence for evolution. Teilhard was aware that even St. Thomas Aquinas had considered the theological compatibility between the Greek Fathers's thought and a more dynamic understanding of the universe:

Was it not St. Thomas [Aquinas] who, comparing (what today we should call the fixist) perspective of Latin Fathers like St. Gregory to the "evolutionary" perspective of the Greek Fathers and St. Augustine, said of the latter, "Magis placet"2 (II Sent, d.12; g.I.a.I)? 
Let us be glad to strengthen our minds by contact with this great thought (Teilhard de Chardin 1968b, p. 154)!

Teilhard advocated "following a line already suggested by the Greek Fathers, to transpose the data of revelation into a universe in movement" (Teilhard de Chardin 1968a, p. 189). What was most pertinent to Teilhard was that the Greek Fathers produced a theology capable of acknowledging the inner journey: "The full mystery of baptism is no longer to cleanse but (as the Greek Fathers understood so well) to plunge into the fire of the purifying struggle 'for being'. No longer the shadow, but the passion of the Cross" (Teilhard de Chardin 1969a, p. 85). Teilhard observed how consciousness unfolds uniquely within every human person, yet this process is directed by the same goal: union with God through Christ, in whom we are transformed and made whole, for Christ is the model of consciousness for union with God.

\subsection{The Ultra-Human}

Knowing oneself is a way of knowing God. Teilhard writes, "No, you do not ask anything false or unattainable of me. You merely, through your revelation and your grace, force what is most human in me to become conscious of itself at least" (Teilhard de Chardin 1960, p. 123). As the human person becomes more whole, it becomes more self-aware. The evolution to a higher level of awareness, or Christ consciousness ${ }^{3}$, integrates all parts of one's being - those which are both humbly human and beatifically divine-in a state of wholeness.

Christ consciousness allows one to be aware that one is not the center of the universe but operates on a higher center of being beyond the ego and participates in life that allows "the possibilities of a universal Communion" (p. 123). This level of consciousness is "a Christianity re-incarnated for the second time in the spiritual energies of Matter" and is "precisely the 'ultra-Christianity' we need now to meet the ever more urgent demands of the 'ultra-human'" (p. 96). The ultra-human, according to Teilhard, is the "reality of an extension beyond the human" (Teilhard de Chardin 1970, p. 313). It is the result of the human person having opened its entire being to a horizon which is transcendent, so that the individual might unite with humanity and all the world as one. Through the gift of self-reflection, the human person can access the cosmic love which radiates from its core. Accessing this love allows the human person to grow more whole and to share in even greater wholeness through uniting with others:

The greater man becomes, the more humanity becomes united, with consciousness of, and master of, its potentialities, the more beautiful creation will be, the more perfect adoration will become, and the more Christ will find, for mystical extensions, a body worthy of resurrection (Teilhard de Chardin 1960, p. 133).

Christ finds mystical extensions in every word, thought, and action working toward wholeness. Every expression of Christ consciousness in humanity is also a birthing of higher consciousness within creation. Every human endeavor that raises the collective consciousness not only plays a vital part of evolution's ascent, but also participates within the Incarnation as an unfolding event, dynamic and still in progress toward achieving universal wholeness.

\section{Universal}

\subsection{The Cosmic Christ}

Teilhard understands all life as being in movement toward greater wholeness, and that this phenomenon stands out in the consciousness of the human person. The person of Jesus reveals a higher degree of awareness while also displaying the possibility for an even more integrated level of conscious relationship: a personal connection with the Universal. The ultimate integration emerged to Teilhard as the Cosmic Christ, the Christ of St. Paul, the Risen Christ in whom "all things hold together" (Col. 1:17). For Teilhard, the Cosmic Christ is the second Person of the Trinity incarnate as not only the historical person of Jesus 
of Nazareth, but also incarnate as the entire body of cosmogenesis. The Cosmic Christ is Universal.

In Teilhard's personal credo, which he penned on two occasions, first in 1934, then again in 1950, he tells of the evolving universe and its consummation in the Universal Christ:

I believe the universe is an evolution:

I believe evolution proceeds toward spirit;

I believe spirit, in human beings, completes itself in the personal;

I believe the supreme personal is the Universal Christ.

(Teilhard de Chardin 1969b, p. 96; Teilhard de Chardin 1978, p. 78)

Teilhard begins his credo by establishing evolution as the foundation of his thought. Next, he identifies the trajectory of evolution toward spirit, which he observes as taking on a personal nature in human beings. The Universal Christ is the pinnacle of evolution, therefore, since the human person is complete only through, with, and in one's relationship with Christ. The Universal Christ is the point in whom the universality of evolution is in relationship with the personal as experienced in human consciousness.

Christ is the universal mover of cosmogenesis. This is what it means for God to draw all things to Godself in Christ. The Universal Christ is "term and motive force of evolution" which is "attainable in and through the whole process of evolution, that is, by animating the total evolution of the cosmos from within" (Cowell 2001, p. 31). This implies Christ is present at every phase of evolution. Christ's task is bringing the cosmos into higher states of consciousness by bringing creation into union with Christself. Union with Christ ultimately leads to wholeness in relationship with the Godhead.

\subsection{The Omega Point}

The Omega Point is the fullness of God's love expressed within the world, or the point of maximum material complexity and maximum consciousness in the universe. Teilhard sourced the word "Omega" from the final letter of the Greek alphabet, illustrating the fullness of Christ at the end of time-" the Alpha and the Omega, the first and the last, the beginning and the end" (Rev. 1:8). According to Thomas King, Teilhard's use of the word "Point", implies "that the final end of the universe is centered and personal" (King 1999, p. 276). The Omega Point is synonymous with the Universal Christ.

Teilhard writes, "'Personalized' being, that makes us human, is the highest state in which we can apprehend the stuff of the world. Carried to its consummation, this substance must still contain to a supreme degree our most precious perfection" (Teilhard de Chardin 1969a, pp. 144-15). Omega, the Universal-Personal, might also be considered to be "superconscious" or "super-personal". Consequently, Teilhard connects the Omega Point with Christ, in whom humanity encounters as the fullness of the Divine within the finitude of creation. The face of Christ Omega is the incomprehensible mind of God made flesh, having suffered and died, and then transformed into a reality of a higher ontology. Siôn Cowell writes how Teilhard saw the Omega Point as the "term of social and spiritual maturation of the earth ... God at the end of creation acting through the mediation of Christ-Omega" (p. 133). This point of maximum consciousness is the fullness of the human person and a fullness of the collective human organism, now spiritually mature-a humanity divinized, assimilated to the Father through, with, and in the Son, the Word, the Likeness and the Image.

Christ Omega, becomes a reality within human history first by way of Jesus of Nazareth: "Once he has been raised to the position of Prime Mover of the evolutive movement of complexity-consciousness, the cosmic-Christ becomes cosmically possible" (Teilhard de Chardin 1978, p. 94). Then humanity, through the person (consciousness) of Christ, can be aware of and in relationship with the powerful and transcendent energies which reveal themselves through evolution, a process that eventually becomes personal in Christogenesis. Christogenesis is the evolutionary stage after cosmogenesis. Teilhard writes: 
For each one of us, every energy and everything that happens, is super-animated by his influence and [Christ's] magnetic power. To sum up, Cosmogenesis reveals itself ... first as Biogenesis and then Noogenesis, and finally culminates in the Christogenesis which every Christian venerates (p. 94).

Veneration, or an act of veneration, might be considered the ascent of consciousness, encountering and beheld by true "wonder and awe". The radiating love of the Cosmic Christ brings the disparate elements of the cosmos into greater unity and yields higher levels of being. Through "loving, co-extensively and co-organically with all the past, the present and the future of a Universe which is in a process of centration upon itself" (Teilhard de Chardin 1978, p. 100) the Cosmic Christ, the Omega Point, becomes increasingly present through consciousness.

Teilhard's Christogenic vision breeds a new kind of mysticism, a mysticism fit for the laypersons of the 20th century and beyond, where one's mystical experience comes in the form of loving God and having faith in the world (p. 102); the practice that leads to this experience comes from giving "all of one's strength and all of one's heart to coinciding with the Focus of universal unification" (p. 95). The fruit of loving God and believing in the world is an awareness of relationship with the God of the future, the God-incarnate in Christ Omega-and the emergence of a more evolved human being.

\section{Apostolic}

\subsection{Participation in the Mystical Body of Christ}

Teilhard writes of his apostolate, "I, Lord, for my very lowly part, would wish to be the apostle and (if I dare be so bold) the evangelist of your Christ in the universe" (Teilhard de Chardin 1968c, p. 219). In this sense, Teilhard's vision is incredibly apostolic. His thought takes on the genesis of created reality and the eschaton, identifying the teleological attractor of the universe as Christ. Inspired by the Church Fathers, his work probes the spiritualization of the universe through the human person's relationship with the Divine. As a professed member of the Society of Jesus, Teilhard was loyal to the Church during his lifetime, never disobeying the sanctions imposed upon him by the Jesuits which restricted him from publishing his spiritual reflections on evolution. Teilhard's work has even been spoken of favorably by Pope John Paul II, Pope Benedict XVI, and Pope Francis, who quotes Teilhard in his encyclical Laudato Si'.

St. Paul was also highly influential on the apostolic mark of Teilhard's catholicity. Teilhard was a pilgrim like Paul on the road to Damascus and then throughout the Roman Empire. Teilhard writes, "I am a pilgrim of the future on my way back from a journey made entirely in the past" (Teilhard de Chardin 1962, p. 60). His study of evolution became a pilgrimage which gained clarity and intensity when he connected his search for the All with the Christ of St. Paul. This journey was also a means by which Teilhard could network with like-minded thinkers, sharing the "good news" as he went.

Teilhard's re-reading of St. Paul catalyzed "an explosion of dazzling flashes" (Teilhard de Chardin 1978, p. 50) as he envisioned the Omega of evolution as one with Christ. Kathleen Duffy writes that the "implosion caused by the coincidence of Christ with the Omega of the Universe released" (Duffy 2014, p. 110) what Teilhard describes as "a light so intense that it transfigured ... the very depths of the World" (Teilhard de Chardin 1978, pp. 82-83). Thus, Teilhard embraced his love for the Earth and of matter for he could comprehend that Christ was at the heart of matter and was alluring him into deeper relationship.

Just as St. Paul declared that in "putting on the mind of Christ", (Phil. 2:5) "God will be all in all" (1 Cor. 15:28), Teilhard proclaims that "when humanity finally transcends itself in Christ, it will inevitably find itself personally immortalized" (Teilhard de Chardin 1969a, p. 116). Teilhard became aware of how his evolution as a single person played a role within the evolution of the human species, and how the evolution of the species was indelibly enmeshed with cosmogenesis and the ushering in of a new reality in Christogenesis. This sense of being set Teilhard's world aflame. He saw Christ's face forming as the world 
evolved toward this ultimate point of convergence and emergence. He was conscious that all of the growth, labor, and suffering which he and the rest of the world experienced could be offered for consecration by God's Holy Fire (Teilhard de Chardin 1978, p. 121). The Fire drew Teilhard beyond contemplating God's presence to embracing the communion. Teilhard understood that to be one with God, he was to be one with the Earth. This meant the task of being as conscious as possible of how his life was evolving toward greater relationship with God through Christ Omega.

\subsection{A Transformation of Consciousness}

Teilhard's catholicity is perhaps best summed up within the story of the transformation from Saul to St. Paul the Apostle. The metamorphosis of the person from Saul to Paul is more than a change in personality and identity. It is a change in religious consciousness of cosmic proportions. Paul's rigid consciousness was challenged by encountering the Mystical Cosmic Body, and then transformed and integrated into a larger community and body of understanding. Likewise, Teilhard's faith is catholic in the universal sense and for this reason challenges a staunchly confessional understanding and practice of the Catholic faith. Teilhard's faith and his spirituality do not oppose a confessional approach, yet surely challenge more myopic perspectives. Teilhard writes, "What I am putting before you are suggestions rather than affirmations. My principal objective is not to convert you to ideas that are still fluid but to open horizons for you, to make you think" (Teilhard de Chardin 1968b, p. 217). In the very way that Teilhard sought to find God in all things, so too does his work call for seekers to stretch beyond limitations and boundaries, impelled by the sheer universality of the Cosmic Christ.

Ilia Delio writes, "evolution is the rise of spirit/consciousness, which means that religion is not a distinct human phenomenon but integral to the spirit of the earth" (p. 102). Teilhard remarks that, "the spirit of the earth discovers a more vital need to worship; from universal evolution God emerges in our minds greater and more necessary than ever" (Teilhard de Chardin 1969c, p. 43). This affirms the notion of an unfolding Incarnation in which, over time created reality becomes increasingly conscious of the Whole: "The whole reveals itself to each of its elements in order to draw it to itself" (Teilhard de Chardin 1969a, p. 60). In this light, the definition of what one means by "God" is expanded. God is reframed from "prime mover and supernatural Being" to "wholeness, depth, and relationality" (Delio 2013, p. 78). Christogenesis is far greater than the evolution of the psychosomatic mass of created reality. Instead, it fills out the more intangible elements of reality-elements of wholeness, depth, and relationship - that allow humans to be in a way that is transformational and Incarnational.

Although the rise in material complexity produces astounding technologies and material realities, the most profound impact on the world is through the spiritual as it becomes phenomenologically real. Teilhard reflects, "It was no longer toward some 'ultramaterial' but, on the contrary, toward some 'ultra-living' that I was trying to identify and fix the ineffable ambience" (Teilhard de Chardin 1978, p. 26). More than an ultimate element, God is found as the personal and transformational dynamic of life, emerging into greater wholeness. Thus, Teilhard's life holds true to his definition of faith. It is not only an intellectual adherence to dogma, but also the deep belief in God's goodness. This consciousness of the divine being within the human allows one to evolve with the ascent of consciousness, growing nearer in relationship with God.

Funding: This research received no external funding.

Institutional Review Board Statement: Not applicable.

Informed Consent Statement: Not applicable.

Data Availability Statement: Not applicable.

Conflicts of Interest: The author declares no conflict of interest. 


\section{Notes}

1 See also "The Ascent of Mt. Carmel”, chapter 5:“This union between God and creatures always exists. By it He conserves their being so that if the union would end they would cease to exist. Consequently, in discussing union with God, we are not discussing the substantial union which is always existing, but the union and transformation of the soul in God. the transformation is supernatural, the other natural."

2 "It is more pleasing".

3 Christ Consciousness is analogous with what can be called Non-Dual Awareness or Buddha Consciousness as described by Richard Rohr, Ken Wilber, Richard Mauric Bucke, et al.

\section{References}

Athanasius. 2011. On the Incarnation. Translated by John Behr. Yonkers: St. Vladimir's Seminary Press.

Catholic Church. 1993. Catechism of the Catholic Church. Washington, DC: USCC Publication Services.

Cowell, Siôn. 2001. The Teilhard Lexicon: Understanding the Language, Terminology, and Vision of the Writings of Pierre Teilhard de Chardin. Portland: Sussex Academic Press.

Delio, Ilia. 2013. The Unbearable Wholeness of Being: God, Evolution, and the Power of Love. Maryknoll: Orbis Books.

Duffy, Kathleen. 2014. Teilhard's Mysticism: Seeing the Inner Face of Evolution. Maryknoll: Orbis Books.

King, Thomas M. 1999. Jung's Four and Some Philosophers: A Paradigm for Philosophy. Notre Dame: Notre Dame Press. Marion, Jim. 2011. Putting on the Mind of Christ: The Inner Work of Christian Spirituality. Charlottesville: Hampton Roads.

St. John of the Cross. 2008. The Dark Night of the Soul. In The Essential St. John of the Cross. Translated by Silverio De Santa Teresa, and E. Allison Peers. Radford: Wilder Publications.

Teilhard de Chardin, Pierre. 1959. The Phenomenon of Man. Translated by Bernard Wall. New York: Harper and Row.

Teilhard de Chardin, Pierre. 1960. The Divine Milieu. New York: Harper and Row.

Teilhard de Chardin, Pierre. 1962. Letters from a Traveler. New York: Harper and Row.

Teilhard de Chardin, Pierre. 1968a. Science and Christ. Translated by René Hague. New York: Harper and Row.

Teilhard de Chardin, Pierre. 1968b. The Vision of the Past. Translated by René Hague. New York: Harper and Row.

Teilhard de Chardin, Pierre. 1968c. Writings in Time of War. Translated by René Hague. New York: Harper and Row.

Teilhard de Chardin, Pierre. 1969a. Christianity and Evolution. Translated by René Hague. New York: Harcourt Brace Jovanovich.

Teilhard de Chardin, Pierre. 1969b. How I Believe. Translated by René Hague. London: Collins.

Teilhard de Chardin, Pierre. 1969c. Human Energy. Translated by J. M. Cohen. New York: Harcourt Brace Jovanovich.

Teilhard de Chardin, Pierre. 1970. Activation of Energy. New York: Harcourt Brace Jovanovich.

Teilhard de Chardin, Pierre. 1978. The Heart of Matter. Translated by René Hague. New York: Harcourt Brace Jovanovich. 